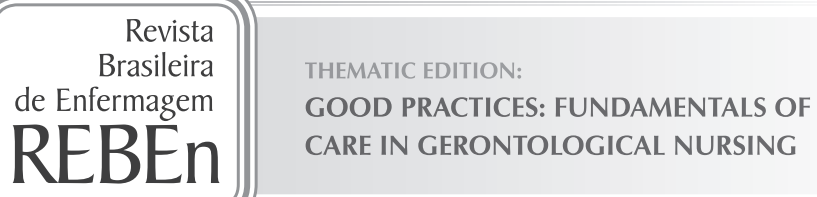

\title{
Elderly who take care of elderly: a study on the Frailty Syndrome
}

\author{
Idosos que cuidam de idosos: um estudo sobre a Síndrome da Fragilidade \\ Ancianos que cuidan a los ancianos: estudio sobre el síndrome de fragilidad
}

\section{Ariene Angelini dos Santos-Orlandi',"I, Tábatta Renata Pereira de Brito"I, Ana Carolina Ottaviani' ${ }^{\text {IV }}$, Estefani Serafim Rossetti ${ }^{\prime v}$, Marisa Silvana Zazzetta', Sofia Cristina Iost Pavarini'}

\author{
' Universidade Federal de São Carlos, Department of Gerontology. São Carlos, São Paulo, Brazil. \\ "Universidade Federal de São Carlos, Department of Nursing. São Carlos, São Paulo, Brasil. \\ II' Federal University of Alfenas, Faculty of Nutrition. Alfenas, Minas Gerais, Brazil. \\ IV Universidade Federal de São Carlos, Postgraduate Program in Nursing. São Carlos, São Paulo, Brazil.
}

\begin{abstract}
How to cite this article:
Santos-Orlandi AA, Brito TRP, Ottaviani AC, Rossetti ES, Zazzetta MS, Pavarini SCl. Elderly who take care of elderly: a study on the Frailty Syndrome. Rev Bras Enferm [Internet]. 2017;70(7):822-9. [Thematic Edition "Good Practices: Fundamentals of care in Gerontological Nursing"] DOI: http://dx.doi.org/10.1590/0034-7167-2016-0474
\end{abstract}

Submission: 10-03-2016 Approval: 04-02-2017

\begin{abstract}
Objective: Identifying prevalence of frailty in elderly caregivers inserted in a high social vulnerability context and its correlation with sociodemographic and health aspects. Method: Descriptive, correlational and cross-sectional study. Forty elderly caregivers were evaluated with: questionnaire for caregiver characterization, Mini Mental State Examination, Katz Index, Lawton instrumental activities of daily living scale, Geriatric Depression Scale and the frailty phenotype proposed by Fried. Interviews were conducted at their residences and scheduled in advance. All ethical precautions were observed. Data were analyzed with the Stata statistical program version 11.0 . Results: $10 \%$ of elderly caregivers were frail. There was a significant correlation between frailty and sex, instrumental activities of daily living and cognition. Conclusion: Female caregivers, partially dependent individuals regarding instrumental activities of daily living and with worse cognitive state deserve a special attention from health services.
\end{abstract}

Descriptors: Caregivers; Fragile Elderly; Geriatric Nursing; Social Vulnerability; Family Health.

\section{RESUMO}

Objetivo: Identificar a prevalência de fragilidade em cuidadores idosos inseridos em contexto de alta vulnerabilidade social e sua correlação com aspectos sociodemográficos e de saúde. Método: Estudo descritivo, correlacional, transversal. Foram avaliados 40 cuidadores idosos utilizando-se: questionário para caracterização do cuidador, Mini Exame do Estado Mental, Índice de Katz, Escala de atividades instrumentais de vida diária de Lawton, Escala de Depressão Geriátrica e o fenótipo de fragilidade proposto por Fried. As entrevistas foram realizadas no domicílio, sendo previamente agendadas. Todos os cuidados éticos foram observados. Os dados foram analisados com apoio do pacote estatístico Stata versão 11.0. Resultados: 10,0\% dos cuidadores idosos eram frágeis. Houve correlação significativa entre fragilidade e: sexo, atividades instrumentais de vida diária e cognição. Conclusão: Cuidadoras do sexo feminino, indivíduos parcialmente dependentes em relação às atividades instrumentais de vida diária e com pior estado cognitivo merecem especial atenção dos serviços de saúde.

Descritores: Cuidadores; Idoso Fragilizado; Enfermagem Geriátrica; Vulnerabilidade Social; Saúde da Família.

\section{RESUMEN}

Objetivo: Identificar la existencia de la fragilidad en ancianos cuidadores en un contexto de elevada vulnerabilidad social y su correlación con aspectos sociodemográficos y sanitarios. Método: Estudio descriptivo, correlacional, transversal. Se evaluaron a cuarenta ancianos cuidadores empleando: un cuestionario para conocer el cuidador, el Miniexamen del Estado Mental, el Índice de Katz, la Escala de actividades instrumentales de la vida diaria de Lawton, la Escala de depresión geriátrica y el fenotipo de fragilidad, de Fried. Se realizaron las entrevistas en las residencias con fecha y horario agendado. Se observaron todos los cuidados éticos. Se evaluaron los datos mediante el software Stata, versión 11. Resultados: Un 10\% de los cuidadores se los 
consideraron frágiles. Fue significativa la correlación entre fragilidad y género, fragilidad y actividades instrumentales de la vida diaria y fragilidad y cognición. Conclusión: Las cuidadoras fueron parcialmente dependientes en relación a las actividades instrumentales de la vida diaria y tuvieron un peor estado cognitivo, por lo que necesitan una asistencia sanitaria especial.

Descriptores: Cuidadores; Anciano Frágil; Enfermería Geriátrica; Vulnerabilidad Social; Salud de la Familia.

\section{CORRESPONDING AUTHOR Ariene Angelini dos Santos-Orlandi Email: arieneangelini@yahoo.com.br}

\section{INTRODUCTION}

Longevous elderly with chronic illnesses and who demonstrate damage on their functional capacity are dependent on a caregiver ${ }^{(1)}$. In Brazil, considering the increase in the number of elderly people who take care of other elderly people, it becomes important that older caregivers are able to provide good quality care and have their cognitive and physical health preserved ${ }^{(1-2)}$.

Regarding the specific case of elderly caregivers inserted in high social vulnerability contexts, conditions for the care are even more critical. This is because social vulnerability means the support absence or difficulty of social security institutions, creating situations that complicate or deny the exercise of social rights of each individual, affecting their social cohesion as well as the ability to respond to adverse situations. In contexts of high social vulnerability, therefore, the risk of illness is higher, which makes damage on quality of life and welfare of individuals greater ${ }^{(3)}$. In addition, in these contexts, comorbidities may be aggravated, and the health of these caregivers could be more fragile $\mathrm{e}^{(4)}$.

Frailty is a multi-dimensional syndrome that involves interaction among biological, psychological and social factors in the course of an individual's life, resulting in a state of higher vulnerability ${ }^{(5)}$. It can be considered a public health problem, considering the impact of this syndrome on older people's quality of life as well as the increase in health service expenses due to adverse events. Therefore, it is necessary to investigate its prevalence and associated factors. Such analysis is necessary for early detection and implementation of appropriate interventions. With this attitude, it is possible to avoid the weakening of more older people and provide a health improvement of those who are already fragile(6).

In the literature, we found some research that verified frailty prevalence among the elderly and its associated factors. A study conducted in Montes Claros (MG) with 511 older people aimed to verify prevalence and factors associated with frailty in non-institutionalized older people. As a result, a $41.3 \%$ frailty prevalence was obtained. Associated factors with frailty were: female sex, advanced age, low educational level, presence of a caregiver, fall in the last year, diabetes mellitus, heart disease and osteoarticular disease ${ }^{(7)}$.

A study carried out in the USA with 7.439 elderly aged 65 or older found a $15 \%$ prevalence of frailty, and the main risk factors were: advanced age, female sex, low income, racial/ethnic minorities and the presence of multiple chronic diseases ${ }^{(8)}$.

It is worth mentioning that research that investigated prevalence of frailty and its correlation with sociodemographic and health aspects regarding elderly caregivers was not found, which justifies the conduction of this study. It is expected that the results can help fill this gap in the Brazilian scientific literature, subsidizing health services in the planning of a quality assistance. Thus, older caregivers (especially the ones who live in a context of high social vulnerability) can also maintain their physical and cognitive health preserved and provide good quality care.

Therefore, this study aimed to identify prevalence of frailty in older caregivers inserted in a high social vulnerability context and its correlation with sociodemographic and health aspects.

\section{METHOD}

\section{Ethical aspects}

All ethical precautions that rule research with human beings were observed and respected, according to Resolution 466/2012, regulated by the Brazilian National Health Council. The study was approved by the Research Ethics Committee on June 9th, 2015.

\section{Study design, location and period}

This is a descriptive, correlational and cross-sectional study, based on the investigation quantitative method. It was held in São Carlos, SP, from September to October 2015.

\section{Sample, inclusion and exclusion criteria}

The population was formed by people aged 60 or older, enrolled and residents in the reach urban area of the Family Health Units (FHU) of the city that assist the elderly. We interviewed all caregivers $(n=40)$ who attended the following inclusion criteria: aged 60 or older; being registered in a FHU inserted in a context of high and very high social vulnerability (São Paulo Social Vulnerability Index 5 and 6 ), belonging to the urban area; being the primary caregiver of an older person residing in the same house; understanding the questions of the interview; accepting to participate and signing the informed consent form. The exclusion criteria were: severe hearing or vision declines that would impair communication; being registered in a FHU belonging to the rural area.

\section{Study protocol}

Data collection began after reading and signing of the informed consent form and were held at a single occasion. The elderly underwent demographic and health characterization as well as functional capacity, depressive symptoms, cognitive state and frailty state measures.

Demographic and health data were collected through a questionnaire previously built by the researchers, comprising the following information: sex, age, marital status, education, 
family, current work arrangement, retirement, income, health insurance, health perception, presence of hypertension, smoking and alcoholism.

To assess the functional capacity, the Katz index for basic activities of daily living ${ }^{(9)}$ and the Lawton instrumental activities of daily living scale ${ }^{(10)}$ were used. Regarding basic activities of daily living, there are three possible scores for each of the items evaluated, according to the dependence level of the patient: independent, needs assistance and dependent. The score can vary between zero and six points according to the dependence level. The older person can be classified as independent, with moderate or severe dependence. Considering the instrumental activities of daily living, the final score can vary between 7 and 21 points, 7 points meaning total dependence, 8 to 20 points indicating partial dependence and 21 points being independence.

To keep track of depressive symptoms, the Geriatric Depression Scale, 15-item version was used. In the end, the sum of the score obtained is carried out so that a result between 0 and 5 points means there is no evidence of depressive symptoms, and between 6 and 15 points indicates the presence of symptoms $^{(11)}$.

Aiming to verify the cognitive state, the tracking test named Mini Mental State Examination was used. The minimum passing scores considered were: 17 for illiterate older people; 22 for the ones with one to four years of education; 24 for those with five to eight years of education; and 26 for those with nine years of education or more ${ }^{(12)}$.

Aiming to assess frailty, the definition proposed by Linda Fried $^{(13)}$ was adopted, although adapted for this study. The syndrome or the frailty phenotype operational definition has five elements:

1. Unintentional weight loss - the following question was asked to caregivers: "Over the past 12 months, do you think you lost weight without being on a diet?" If so, whether this loss of weight is equal to or higher than 4.5 $\mathrm{kg}$ or $5 \%$ of the body weight in the previous year, the older person scored for frailty in this criterion.

2. Fatigue - assessed through self-report obtained by two questions of the Center for Epidemiological Studies Depression (CES-D) (a scale for depression tracking): 7"How often in the last week did you feel that everything you have done required a big effort?"; and 20 - "How often in the last week did you feel you could not carry out your tasks?". Older people who answered "always" or "mostly" for either of these two questions received a point for frailty in this criterion.

3. Palm prehension low strength - it was measured with a portable hydraulic dynamometer in the dominant hand. Three consecutive measures of palm prehension force were carried out using the arithmetic mean. To fill the criterion, the result was adjusted according to the sex and the Body Mass Index (BMI), according to Fried ${ }^{(13)}$.

4. Low level of caloric expenditure (adapted) - assessed through self-report obtained through the question "Do you do less physical activity than 12 months ago?" If the answer was yes, the older person received a point for frailty in this criterion.

5. Slow gait - indicated by the average time spent to go through $4.6 \mathrm{~m}$ distance, with adjustments according to sex and height. Three measurements of the gait speed were carried out by using the arithmetic mean, as proposed by Fried ${ }^{(13)}$.

The presence of three or more of the five characteristics of a frail older person indicates phenotype; one or two means that the elderly lies in the State of pre-frailty; and none of these features indicate a robust or not fragile older person ${ }^{(13)}$.

\section{Data analysis}

Data were coded and typed into a digital spreadsheet and analyzed with the support of the Stata version 11.0 statistical program. They were analyzed with descriptive statistics and presented on a frequency table, with absolute values (n) and percentage (\%) for the categorical variables, and with measures of location and dispersion (mean, standard deviation, median, minimum and maximum values) for continuous variables. Due to the non-adherence to the variables' normal distribution as verified by the Shapiro-Wilk test, we chose the non-parametric tests. The t-test and the Fisher's Exact Test were carried out to estimate differences between the groups. The significance level adopted was 5\% ( $\leq \leq 0.05)$.

\section{RESULTS}

Regarding caregivers' frailty, 50\% were pre-frail; $40 \%$ not frail; and $10 \%$ frail. Considering the IADL, $52.5 \%$ were independent; and $47.5 \%$, partially dependent. Regarding BADL, $72.5 \%$ were independent, and $27.5 \%$ presented moderate dependence. The predominant characteristics of the forty older caregivers who took part in this research are described on Table 1.

Most older caregivers, $92.5 \%(n=37)$, showed no signs of cognitive deficit. Among these, 43.2\% were considered not frail; $51.4 \%$, pre-frail; and $5.4 \%$, frail. Regarding older caregivers who showed signs of cognitive changes, none were considered not frail, $33.3 \%$ were considered pre-frail, and $66.7 \%$, frail.

According to the t-test, there was a statistically significant difference between the means of points in the MMSE according to the frailty. Frail individuals presented 19.80 points at the MMSE, while not frail individuals presented 23.82. This means frail individuals showed worse cognitive state when compared with not frail individuals. Table 2 shows the difference between the means of points in the MMSE according to frailty, in such a way that frail and pre-frail older people were grouped in the same category.

Through the Fisher's Exact Test, correlation was found between level of frailty and the variables sex and IADL. We observed that among the frail older people, the highest percentage corresponds to women and partly dependent individuals regarding the IADL (Table 3). The results of the correlation between variables of interest and frailty are presented on Table 3. 
Table 1 - Distribution of the predominant characteristics of the elderly caregivers, São Carlos, São Paulo, Brazil, 2015 ( $n=40$ )

\begin{tabular}{|c|c|c|c|c|c|c|}
\hline Questions & Categories & $\mathbf{n}$ & $(\% *)$ & Mean (SD) & [Min-Max] & Median \\
\hline Sex & Female & 27 & 67.5 & & & \\
\hline Age (years) & & & & $70.1(8.2)$ & [60-98] & 68.5 \\
\hline Age group & $60-69$ years old & 22 & 55.0 & & & \\
\hline Marital status & Married & 35 & 87.5 & & & \\
\hline Family arrangement & Live with spouse & 37 & 92.5 & & & \\
\hline Years of education & & & & $1.8(2.3)$ & {$[0-12]$} & 1.0 \\
\hline Educational level & One to four years & 16 & 40.0 & & & \\
\hline Currently have a job & No & 33 & 82.5 & & & \\
\hline Retirement & Yes & 29 & 72.5 & & & \\
\hline Income (dollars) & & & & $781.2(382.0)$ & [0-2000] & 780.0 \\
\hline Health plan & No & 36 & 90.0 & & & \\
\hline Health perception & Reasonable & 19 & 47.5 & & & \\
\hline Arterial Hypertension & Yes & 25 & 62.5 & & & \\
\hline Smoking & Never smoked & 17 & 42.5 & & & \\
\hline Alcoholism & No & 36 & 90.0 & & & \\
\hline IADL & Independence & 21 & 52.5 & & & \\
\hline BADL & Independence & 29 & 72.5 & & & \\
\hline GDS Score & & & & $4.5(2.8)$ & [0-9] & 4.0 \\
\hline GDS & No signs of depression & 23 & 57.5 & & & \\
\hline MMSE Score & & & & $21.5(4.7)$ & [9-29] & 22.0 \\
\hline MMSE Result & Without evidence of changes & 37 & 92.5 & & & \\
\hline Level of frailty & Pre-frail & 20 & 50.0 & & & \\
\hline
\end{tabular}

Note: SD - standard deviation; IADL - Instrumental Activities of Daily Living; BADL - Basic Activities of Daily Living; GDS - Geriatric Depression Scale; MMSE Mini Mental State Examination.

Table 2 - Correlation between the means of points on the Mini Mental State Examination according to frailty, São Carlos, São Paulo, Brazil, $2015(\mathrm{n}=40)$

\begin{tabular}{lccccc}
\hline Frailty & $\mathbf{n}$ & Mean & Standard error & S-D* & Clt \\
\hline Not frail & 17 & 23.82 & 0.86 & 3.55 & $21.99-25.65$ \\
Frail & 23 & 19.80 & 1.01 & 4.87 & $17.67-21.89$ \\
\hline
\end{tabular}

Note: $* S-D=$ standard deviation; $+C I=$ confidence interval; $\neq p<0.05$ according to the t-test. 
Table 3 - Correlation between levels of frailty and variables of interest, São Carlos, São Paulo, Brazil, 2015 (n = 40)

\begin{tabular}{|c|c|c|c|}
\hline Questions & Not frail (\%) & Frail (\%) & $p$ value \\
\hline Sex & & & $0.044^{* *}$ \\
\hline Female & 47.1 & 78.3 & \\
\hline Male & 52.9 & 21.7 & \\
\hline Age group & & & 0.677 \\
\hline 60 to 74 years old & 88.2 & 78.3 & \\
\hline 75 years old or older & 11.8 & 21.7 & \\
\hline Marital status & & & 0.197 \\
\hline Married & 94.1 & 82.6 & \\
\hline Single & 5.9 & 0.0 & \\
\hline Divorced & 0.0 & 4.4 & \\
\hline Widower & 0.0 & 13.0 & \\
\hline Health self-perception & & & 0.598 \\
\hline Excellent & 5.9 & 4.4 & \\
\hline Good & 23.5 & 30.4 & \\
\hline Moderate & 58.8 & 39.1 & \\
\hline Bad & 11.8 & 26.1 & \\
\hline Arterial hypertension & & & 0.107 \\
\hline Yes & 47.0 & 73.9 & \\
\hline No & 53.0 & 26.1 & \\
\hline Geriatric Depression Scale & & & 0.202 \\
\hline No signs of depression & 70.6 & 47.8 & \\
\hline Signs of depression & 29.4 & 52.2 & \\
\hline Smoking & & & 0.912 \\
\hline Currently smokes & 17.6 & 17.4 & \\
\hline Used to be a smoker & 35.3 & 43.5 & \\
\hline Never smoked & 47.1 & 39.1 & \\
\hline Alcoholism & & & 1.000 \\
\hline Yes & 11.8 & 8.7 & \\
\hline No & 88.2 & 91.3 & \\
\hline IADL & & & $0.002 * *$ \\
\hline Independence & 82.3 & 30.4 & \\
\hline Partial dependence & 17.7 & 69.6 & \\
\hline BADL & & & 0.626 \\
\hline Independence & 76.5 & 69.6 & \\
\hline $\begin{array}{l}\text { Moderate depend- } \\
\text { ence }\end{array}$ & 23.5 & 21.7 & \\
\hline Severe dependence & 0.0 & 8.7 & \\
\hline Health plan & & & 1.000 \\
\hline Yes & 11.8 & 8.7 & \\
\hline No & 88.2 & 91.3 & \\
\hline Currently have a job & & & 0.432 \\
\hline Yes & 23.5 & 13.0 & \\
\hline No & 76.5 & 87.0 & \\
\hline Retirement & & & 0.730 \\
\hline Yes & 76.5 & 69.6 & \\
\hline No & 23.5 & 30.4 & \\
\hline
\end{tabular}

Note: IADL - Instrumental Activities of Daily Living; BADL - Basic Activities of Daily Living. *Fisher's Exact Test; ${ }^{*} p<0.05$.

\section{DISCUSSION}

In this study, there was a statistically significant correlation between frailty and sex. Women showed to be more frail than men. These data were corroborated by other studies present in the literature ${ }^{(13-15)}$.

An American study was conducted with 5.317 American older people ( $\geq 65$ years old). As results, they achieved a $6.3 \%$ frailty prevalence ( $7.3 \%$ women and $4.9 \%$ men), $48.3 \%$ frailty and $45.3 \%$ pre-frailty. There was a significant association between frailty and the variables sex and age. The highest frailty prevalence was noticed on advanced age people and women ${ }^{(13)}$.

Living conditions marked by sexual differences, such as performance of house chores, lack of economic independence and restricted social life are factors that can explain the highest frailty prevalence among women ${ }^{(16)}$.

In addition, surveys indicate that muscle strength and the amount of lean body mass is lower on females when compared with males, considering the same age group. Furthermore, women may be more exposed to extrinsic factors (e.g., inadequate nutritional ingestion) that cause the sarcopenia, which could explain the higher incidence of frailty among women ${ }^{(17)}$.

Other authors report that the highest prevalence of frailty in the females is due to the greater longevity of women compared with men. In this context, there is an increase in female predisposition to chronic diseases, since with the aging process there are physiological and functional modifications that make the elderly more susceptible to diseases. Appearing of diseases can cause physical limitations, turning elderly into more frailer people, in addition to increase the risk of adverse situations to health ${ }^{(14)}$.

In this research, there was a significant statistically correlation between frailty and instrumental activities of daily living. We observed that among frail older people, the highest percentage corresponds to partly dependent individuals regarding the IADL. There are studies in the literature that corroborate these findings ${ }^{(13,15,18-19)}$.

An investigation was carried out with 117 older people $(70.1 \pm 7.3$ age mean), of whom mostly were women, with low income and low education. The results showed that $51.3 \%$ of the elderly were pre-frail, followed by the frail ones and a minority of non-frail ones. Regarding the Lawton index, there was a predominance of independent older people in the IADL. There was a significant association between frailty and the IADL. Frail older people showed worse functional performance when compared with the non-frail ones. The authors concluded that these findings reinforce the assumption that frailty compromises the functionality of the elderly ${ }^{(18)}$.

In the Netherlands, a research was conducted with 8.684 older people who lived in the community. The obtained results were the following: $63.2 \%$ of the participants were not frail, $28.1 \%$ were pre-frail and $8.7 \%$ were frail. Frail older people had more problems with the performance of the IADL when compared with non-frail individuals, and this association was significant ${ }^{(15)}$.

In Mexico, 558 older people formed a sample of a crosssectional study in order to estimate prevalence of frailty in older people from rural areas who lived in social vulnerability situations. As results, the authors found that $8.6 \%$ were frail, $52.9 \%$ pre-frail and $38.5 \%$ not frail. Illiteracy and inability in daily living 
activities increase the probability of older people becoming frail, while high socioeconomic level reduces this probability ${ }^{(19)}$.

It is noteworthy the presence of frailty does not necessarily mean that the elderly will be dependent in relation to activities of daily living. Researchers claim that, when the elderly person becomes dependent and frail, more complex activities are the first to be affected, and then and in a smaller proportion, the simplest activities of the routine ${ }^{(17)}$. Limitations in performance of daily living activities have a negative impact on older people's quality of life, raising the risk for dependency, institutionalization and death ${ }^{(20)}$.

Functional independence is strongly influenced by mobility of older people. With aging, decrease in muscle mass and strength can affect the lower limbs, compromising the functional capacity $^{(20)}$.

Maintaining functionality of the elderly can cause implications for quality of life and autonomy, by making these older people remain in the community, enjoying their independence and company of the family. Decline in performance of daily living activities can lead to increased risk of incidence of chronic diseases or weakness ${ }^{(18)}$.

In this study, there was a statistically significant correlation between frailty and sex. Researchers claim that this relationship in the elderly who do not have dementia is complex and is named cognitive weakness. It is a medical condition characterized by the simultaneous occurrence between frailty and cognitive impairment and absence of dementia diagnosis or other neurological impairment ${ }^{(21)}$.

In the literature, other studies have also detected an association between cognitive impairment and frailty, which were carried out at different contexts, such as: United States of America $^{(22)}$; Brazil(23); Canada ${ }^{(24)}$ and Mexico ${ }^{(25)}$.

A Finnish study was conducted with 654 older people, being 82 the average age. As results, the authors found that $48 \%$ of them were pre-frail; $38 \%$, not frail; and $14 \%$, frail. From all of the older people, $26 \%$ presented cognitive changes; and among the frail ones, $64 \%$ presented them. Frail older people were eight times more likely to develop cognitive changes, four times more likely to develop Alzheimer's disease and six times more likely for vascular dementia. When compared with the pre-frail and not frail elderly, frail individuals were older, had more chronic diseases and were more dependent in activities of daily living ${ }^{(26)}$.

Elderly people in Belém (Pará, Brazil) and Ermelino Matarazzo (São Paulo, Brazil) ( $n=878$ ) formed a sample research, derived from the FIBRA Study (Frailty in the Brazilian Elderly), which identified $50 \%$ pre-frail elderly; $42 \%$ not frail; and $8 \%$, frail. There was a statistically significant difference between the MMSE scores for frail, pre-frail and not frail older people. Frail older people had worse functional performance in the MMSE when compared with the non-frail ones.

A longitudinal work was conducted with 207 older people in order to evaluate the association between frailty and cognitive decline and the incidence of cognitive change, in 12 months. The results showed that $54.1 \%$ of the elderly were pre-frail; $23.2 \%$ were frail; and $22.7 \%$ were not frail. Approximately $6 \%$ of the non-frail elderly, $25 \%$ of the pre-frail ones and $58.3 \%$ of the frail ones presented cognitive impairment.
Frailty was associated with a subsequent decline of the cognitive function in 12 months when measured by the MMSE ( $\mathrm{p}=$ 0.005; Relative Risk $=4.6 ; 95 \% \mathrm{Cl} 1.93-11.2$ ). Incidence of cognitive changes was $4.9 \%$ for the non-frail elderly, $8.9 \%$ for the pre-frail ones and $13.3 \%$ for the frail ones ${ }^{(23)}$.

A cross-sectional study carried out with 273 Japanese women who lived in the community aimed to determine whether frailty and pre-frailty would be associated with cognitive decline and sarcopenia. Frail older people were more likely to develop cognitive decline and sarcopenia when compared with non-frail ones. Pre-frailty was only associated with sarcopenia ${ }^{(28)}$.

Literature points out some factors that are associated with both frailty and low cognitive performance. Among them, highlights include advanced age, female gender, low socioeconomic status, dependence in activities of daily living, presence of comorbidities and depressive symptoms ${ }^{(23,26-27,29)}$.

Scholars claim that there seem to be a biological association between cognitive decline and frailty, and that these two conditions may share the same physiopathological mechanisms. Both conditions involve inflammatory processes, neuroendocrine deregulation, and oxidative stress ${ }^{(30)}$. Chronic inflammation carries out a fundamental role in the pathogenesis of frailty, and steep levels of inflammatory cytosines were also associated with cognitive impairment. In addition, neuroendocrine deregulation is involved with both frailty and cognitive impairment ${ }^{(31)}$.

Other researchers suggest that lifestyle can display common risk factors for both frailty and cognitive decline, such as sedentarism, smoking, presence of comorbidities, which contribute simultaneously to both conditions. Hence, it is possible that such factors interact with each other, leaving uncertain the causal association between frailty and cognitive decline ${ }^{(28)}$.

However, it is believed that those are not the only factors that would explain the relationship between frailty and cognitive decline, as it is about complex conditions, in such a way that other factors are probably also involved ${ }^{(23)}$. In this sense, more studies are needed to elucidate this association, since not all patients with cognitive changes become frail and vice versa.

It is worth highlighting that the combination of frailty and cognitive changes can enhance vulnerability of the elderly and influence the subsequent cognitive decline ${ }^{(23)}$. Recent surveys reinforce that cognition is an important factor to be considered regarding the phenotype of the frailty syndrome, which would increase the measurement capacity of such syndrome ${ }^{(28)}$. Older people with cognitive decline may have more difficulties when it comes to feeding and practice of physical activity, which may lose weight and suffer losses in motor function, favoring the beginning and progression of the syndrome ${ }^{(17)}$.

Whereas elderly caregivers who took part in this research were inserted in a context of high social vulnerability, it is worth mentioning that worse economic condition has been associated with higher prevalence of frailty. A group of researchers from the United Kingdom, for example, using data from the Cohort Study Hertfordshire, showed that frailty is partly determined by social inequality ${ }^{(32)}$.

Thus, results found in this research deserves further attention by representing the condition of vulnerable caregivers not only by age, but also by the adverse social environment in which they live. 
The aforementioned studies reflect research with elderly people, not necessarily elderly caregivers. The gap in the literature when it comes to the association between frailty and cognition of elderly caregivers, unfortunately limits further discussion of the findings of this research.

This research had strengths, including the original character of the topic, the fact that the elderly caregivers were residents in the community who were not selected based on cognitive impairment or frailty state. Besides, frailty validated measures were identical to those used in the definition proposed by Linda Fried.

Studies on cognition and frailty of elderly caregivers must be performed, considering the existent small number in both national and international literature. In this sense, longitudinal research must be considered in order to assign causality between the variables of interest.

\section{Limitations of the study}

The limitation of this study is the small sample size, which may introduce an inference error, reduce power of analysis and limit generalization.

Contributions to the fields of nursing, public health or public policy

Regarding contributions, the results observed may alert health professionals, specially nurses, to early identification of frailty, through a global evaluation of the older person aiming at the implementation of a care plan for prevention or reversion of the syndrome. It is worth emphasizing the growing tendency of demand for care for the elderly and that this demand is mostly assisted by family caregivers, also often elders. In this sense, the observed results can guide reformulation of public policies for the elderly in order to fully embrace health of caregivers.

\section{CONCLUSION}

Older frail caregivers assessed are female, with partial dependence regarding IADL and with cognitive impairment. Knowing these characteristics can help the orientation of specific actions for prevention of frailty. In addition, these findings may bring contributions to the implementation of a policy of attention to elderly caregivers within the Family Health Strategy.

On those results, it becomes essential for nurses to provide caregivers adequate support. Support groups can be formed to ensure monitoring of these caregivers, meet their demands and improve their quality of life.

\section{FUNDING}

The complete study was funded by the Coordination for the Improvement of Higher Education Personnel (CAPES).

\section{REFERENCES}

1. Tomomitsu MRS, Perracini MR, Neri AL. [Factors associated with satisfaction with life among elderly caregivers and noncaregivers]. Ciênc Saúde Colet [Internet]. 2014 [cited 2016 Oct 03];19(8):3429-40. Available from: http://www.scielo.br/pdf/csc/ v19n8/1413-8123-csc-19-08-03429.pdf Portuguese.

2. Rocha ACO, Mota FRN, Silva MJ, Bonates LAM, Rocha ACO. Qualidade de vida de idosos que cuidam de idosos no domicílio. Rev Enferm UFPE [Internet]. 2015 [cited 2016 Sep 18];9(2):548-57. Available from: http://www.repositorio.ufc.br/handle/riufc/10726

3. Andrew MK. Frailty and Social Vulnerability. Interdiscip Top Gerontol Geriatr [Internet]. 2015 [cited 2017 Mar 20]41(1):186-95, 2015. Available from: https://www.ncbi.nlm.nih.gov/pubmed/26301990

4. Morley JE, Vellas B, van Kan GA, Anker SD, Bauer JM, Bernabei R, et al. Frailty consensus: a call to action. J Am Med Dir Assoc [Internet]. 2013 [cited 2016 Mar 28];14(6):392-7. Available from: https://www.ncbi.nlm.nih.gov/pubmed/23764209

5. Clegg A, Young J, Iliffe S, Rikkert MO, Rockwood K. Frailty in elderly people. Lancet [Internet]. 2013 [cited 2016 Sep 14];381(9868):752-62. Available from: https://www.ncbi.nlm.nih.gov/pubmed/23395245

6. Lacas A, Rockwood K. Frailty in primary care: a review of its conceptualization and implication for pratice. BMC Med [Internet]. 2012 [cited 2016 Jun 14];10(1):4. Available from: https://www.ncbi.nlm.nih.gov/pubmed/22236397

7. Carneiro JA, Ramos GCF, Barbosa ATF, Mendonça JMG, Costa FM, Caldeira AP. Prevalence and factors associated with frailty in non-institutionalized older adults. Rev Bras Enferm [Internet]. 2016 [cited 2016 Oct 03];69(3):435-42. Available from: http://www. scielo.br/pdf/reben/v69n3/en 0034-7167-reben-69-03-0435.pdf

8. Bandeen-Roche K, Seplaki CL, Huang J, Buta B, Kalyani RR, Varadhan R, et al. Frailty in older adults: a nationally representative profile in the United States. J Gerontol A Biol Sci Med Sci [Internet]. 2015 [cited 2016 set 12];70(11):1427-34. Available from: https://www.ncbi.nlm.nih.gov/pubmed/26297656

9. Katz S, Ford AB, Moskowitz RW, Jackson BA, Jaffe MW. Studies of illness in the aged. The Index of ADL: a standardized measure of biological and psychosocial function. JAMA. 1963;185(12):914-9.

10. Lawton MP, Brody EM. Assessment of older people: self-maintaining and instrumental activities of daily living. Gerontol. 1969;9(3):179-86.

11. Yesavage JA, Brink TL, Rose TL, Lum O, Huang V, Adey M, et al. Development and validation of a geriatric depression screening scale: A preliminary report. J Psychiatr Res. 1983;17(1):37-49.

12. Brucki SMD, Nitrini R, Caramelli P, Bertolucci PHF, Okamoto IH. Sugestões para uso do Mini-Exame do Estado Mental no 
Brasil. Arq Neuropsiquiatr [Internet]. 2003 [cited 2016 Oct 03];61(3B):777-81. Available from: http://www.scielo.br/pdf/anp/ v61n3B/17294.pdf

13. Fried LP, Tangen CM, Walston J, Newman AB, Hirsch C, Gottdiener J, et al. Frailty in older adults: evidence for a phenotype. J Gerontol Biol Sci Med Sci [Internet]. 2001 [cited 2016 Jun 17];56(3):M146-56. Available from: https://www.ncbi.nlm.nih.gov/ pubmed/11253156

14. Santos PHS, Fernandes MH, Casotti CA, Coqueiro RS, Carneiro JAO. Perfil de fragilidade e fatores associados em idosos cadastrados em uma Unidade de Saúde da Família. Ciênc Saúde Colet [Internet]. 2015[cited 2016 Oct 03];20(6):1917-24. Available from: http://www.scielo.br/pdf/csc/v20n6/1413-8123-csc-20-06-1917.pdf

15. Op het Veld LPM, Rossum EV, Kempen GIJM, Vet HCW, Hajema KJ, Beurskens AJHM. Fried phenotype of frailty: cross-sectional comparison of three frailty stages on various health domains. BMC Geriatr [Internet]. 2015 [cited 2016 Mar 26];15(1):77. Available from: https://www.ncbi.nlm.nih.gov/pubmed/26155837

16. Duarte MCS, Fernandes MGM, Rodrigues RAP, Nóbrega MML. Prevalência e fatores sociodemográficos associados à fragilidade em mulheres idosas. Rev Bras Enferm [Internet]. 2013 [cited 2016 Oct 03];66(6):901-6. Available from: http://www.scielo.br/pdf/reben/ v66n6/14.pdf

17. Mello AC, Engstrom EM, Alves LC. Health related and sociodemographic factors associated with frailty in the elderly: a systematic literature review. Cad Saúde Pública [Internet]. 2014 [cited 2016 Mar 23]; 30(6):1-25. Available from: https://www.ncbi.nlm.nih. gov/pubmed/25099040

18. Lustosa LP, Marra TA, Pessanha FPAS, Freitas JC, Guedes RC. Fragilidade e funcionalidade entre idosos frequentadores de grupos de convivência em Belo Horizonte, MG. Rev Bras Geriatr Gerontol [Internet]. 2013 [cited 2016 Oct 03];16(2):347-54. Available from: http://www.scielo.br/pdf/rbgg/v16n2/14.pdf

19. Manrique-Espinoza B, Salinas-Rodríguez S, Snyder NS, Moreno-Tamayo K, Gutiérrez-Robledo LM, Ávila-Funes JA. Frailty and social vulnerability in mexican deprived and rural settings. J Aging Health [Internet]. 2016 [cited 2016 Jun 20];28(4):740-52. Available from: https://www.ncbi.nlm.nih.gov/pubmed/26464372

20. Fernandes $\mathrm{HCL}$, Gaspar JC, Yamashita $\mathrm{CH}$, Amendola F, Alvarenga MRM, Oliveira MAC. Frailty assessment in the elderly assisted at a Family health unit. Texto Contexto Enferm [Internet]. 2013 [cited 2016 Oct 03];22(2):423-31. Available from: http://www. scielo.br/pdf/tce/v22n2/en_v22n2a19.pdf

21. Canevelli M, Cesari M. Cognitive frailty: what is still missing? J Nutr Health Aging [Internet]. 2015 [cited 2016 Mar 27];19(3):2735. Available from: http://link.springer.com/article/10.1007/s12603-015-0464-5

22. Gray SL, Anderson AM, Hubbard AR, La Croix A, Crane PK, McCormick W, et al. Frailty and incident dementia. J Gerontol A Biol Sci Med Sci [Internet]. 2013 [cited 2016 Jun 29];68(9):1083-90. Available from: https://www.ncbi.nlm.nih.gov/pubmed/23419778

23. Alencar MA, Dias JMD, Figueiredo LC, Dias RC. Frailty and cognitive impairment among community-dwelling elderly. Arq Neuropsiquiatr [Internet]. 2013 [cited 2016 Oct 03];71(6):362-7. Available from: http://www.scielo.br/pdf/anp/v71n6/0004-282X-anp-71-06-362.pdf

24. Rolfson DB, Wilcock G, Mitnitki A, King E, Jager CA, Rockwood K, et al. An assessment of neurocognitive speed in relation to frailty. Age Ageing [Internet]. 2013 [cited 2016 set 02];42(2):191-6. Available from: https://www.ncbi.nlm.nih.gov/pubmed/23296141

25. Sánches-García S, Sánches-Arenaz R, García-Peña C, Rosas-Carrasco O, Ávila-Funes JA, Ruiz-Arregui L, et al. Frailty among community-dwelling elderly Mexican people: prevalence and association with sociodemographic characteristics, health state and the use of health services. Geriatr Gerontol Int [Internet]. 2014 [cited 2016 Sep 05];14(2):395-402. Available from: https://www. ncbi.nlm.nih.gov/pubmed/23809887

26. Kulmala J, Nykänen I, Mänty M, Hatikainen S. Association between frailty and dementia: a population-based study. Gerontol [Internet]. 2014 [cited 2016 Sep 05];60(1):16-21. Available from: https://www.ncbi.nlm.nih.gov/pubmed/23970189

27. Santos AA, Mansano-Schlosser TC, Ceolim MF, Pavarini SCl. [Sleep, fragility and cognition: a multicenter study with Brazilian elderly]. Rev Bras Enferm [Internet]. 2013 [cited 2016 Oct 03];66(3):351-7. Available from: http://www.scielo.br/pdf/reben/v66n3/ a08v66n3.pdf Portuguese.

28. Nishiguchi S, Yamada M, Fukutani N, Adachi D, Tashiro Y, Hotta T, et al. Differential association of frailty with cognitive decline and sarcopenia in community-dwelling older adults. JAMDA [Internet]. 2015 [cited 2016 Sep 05];16(2):120-4. Available from: https://www.ncbi.nlm.nih.gov/pubmed/25244957

29. Vaughan L, Corbin AL, Goveas JS. Depression and frailty in later life: a systematic review. Clin Int Aging [Internet]. 2015 [cited 2016 Mar 28];10(1):1947-58. Available from: https://www.ncbi.nlm.nih.gov/pubmed/26719681

30. Mulero J, Zafrilla P, Martinez-Cacha A. Oxidative stress, frailty and cognitive decline. J Nutr Health Aging [Internet]. 2011 [cited 2016 Sep 05];15(9):756-60. Available from: https://www.ncbi.nlm.nih.gov/pubmed/22089224

31. Walston J, McBurnie MA, Newman A, Tracy RP, Kop WJ, Hirsch CH, et al. Frailty and activation of the inflammation and coagulation systems with and without clinical comorbidities: results from the Cardiovascular Health Study. Arch Intern Med [Internet]. 2002 [cited 2016 Sep 05];162(20):2333-41. Available from: https://www.ncbi.nlm.nih.gov/pubmed/12418947

32. Syddall H, Roberts HC, Evandrou M, Cooper C, Bergman, H, Aihie Sayer A. Prevalence and correlates of frailty among communitydwelling older men and women: findings from the Hertfordshire Cohort Study. Age Ageing [Internet]. 2010 [cited 2017 Jan 28];39(2):197-203. Available from: https://www.ncbi.nlm.nih.gov/pubmed/20007127 